\title{
Die herkoms, intensie en metode van die "nuwe" Politieke Teologie van Johann Baptist Metz ${ }^{1}$
}

\author{
Murray Hofmeyr \\ Departemente van Filosofie en Godsdienskunde \\ Universiteit van Venda vir Wetenskap en Tegnologie
}

\begin{abstract}
The genesis, intention and method of the "new" Political Theology of Johann Baptist Metz

This article describes J B Metz's "transcendental phase", when he worked on reformulating scholastic theology within the concepts of twentieth century anthropology. The major categories of Metz's early thought are described in anticipation of the turn away from anthropology to the philosophy of history. The division of theological history into periods with the help of the categories anthropocentrism, theocentrism and cosmocentrism, and the distinction between conceptual framework and conceptual content, allow Metz to argue for the legitimacy of the modern era from a Christian (and specifically Catholic) point of view.
\end{abstract}

\section{INLEIDING}

"Ik bün all hier" sê een van die twee krimpvarkies elke keer vir die hasie in die Nederduitse sprokie. ${ }^{2}$ Johann Baptist Metz (1977:143), stigter van die "nuwe" Politieke

\footnotetext{
${ }^{1}$ Hierdie artikel is gebaseer op navorsing gedoen vir 'n DD-proefskrif van H M Hofmeyr met die titel "'n Teologie van die verlange. Concupiscentia in die Politieke Teologie van Johann Baptist Metz". Die proefskrif is voorberei onder leiding van prof dr C J Wethmar, Fakulteit Teologie, Universiteit van Pretoria.

2 Die Amerikaanse uitgawe van Glaube in Geschichte und Gesellschaft bevat 'n weergawe van die sprokie (Metz 1980:161). Dit is 'n ekwivalent van die storie van hasie en skilpad se resies. Die verskil is dat skilpad in die geheim aan sy vrou opdrag gee om aan die ander kant van die "baan" stelling in te neem. Die hasie hol so al wat hy kan, maar die skilpad is altyd "reeds daar".
} 
Teologie, kies die kant van die hasie en lees so die sprokie "teen sy grein". Die opsie vir die hasie funksioneer as 'n korrektief: dit wil die idealistiese redding van die bedreigde identiteit van die Christendom krities ontmasker.

"Idealisties" beteken hier om die geskiedenis vry te spring - "die Geschichte [zu] hintergehen" (Metz 1977:144). Volgens Metz is daar twee teologiese benaderings wat in hierdie sin idealisties is. Die een is transendentaal-idealisties en die ander universeelhistories-idealisties. In die eerste word die bedreigde historiese identiteit van die Christendom transendentaal beveilig teen die hoë prys van die verwarring van identiteit met toutologie. Toutologie: Die een krimpvarkie is soos die ander, die begin soos die einde, die paradys soos die eindtyd, die skepping soos die voleinding - aan die einde word die begin herhaal. Die geskiedenis self - met sy altyd bedreigde, oorwinbare vorme van identiteit - kom nie daarin voor nie (Metz 1977:145).

In die tweede "idealistiese" benadering het die finaal toegesegde heilsin van die geskiedenis verstar tot 'n denkbepaling wat nie te irriteer is deur kollektiewe historiese angste en die dreigende vernietiging van sin nie. Dit is reeds van alle teenstrydighede bevry, "sie ist sozusagen 'hoffnungslos' total" (Metz 1977:144).

Die omvattende probleem wat hier met verwysing na Metz se Politieke Teologie aangespreek word, is die probleem van Christelike praksis binne die konteks van die burgerlike ruilmaatskappy. Metz se formulering van die probleem in indiwidueel-eksistensiële terme in sy sogenaamde transendentale fase geskied veral binne die raamwerk van sy pogings om die begrip concupiscentia (begeerlikheid) adekwaat te herformuleer. Rahner (1954) het reeds concupiscentia in die engste teologiese sin onderskei van ander soorte begeerlikheid, en dit beskryf as die spontane begeerte van die mens in so verre dit sy vrye besluitneming voorafgaan en daarteen weerstand bied. Soos Metz toenemend bewus raak van die sosiaal-maatskaplike konteks van die teologie, kritiseer hy sy eie vorige posisie, kritiek wat natuurlik ook aan die adres van sy leermeester Rahner gerig is. Hierdie kritiek kom daarop neer dat Metz aanvoer dat die historiese mense van die burgerlike maatskappy in werklikheid nie hulle heelheid besit in transendering op God as die absolute geheimenis nie, maar op die maatskappy as "verblindingssamehang" (Adorno). Rahner se "Vorgriff", sou 'n mens kon sê, sien in werklikheid op die maatskappy as geheel. Dit kom daarop aan om die betekenis van concupiscentia binne hierdie verband te omskryf. 
Die spesifieke probleem wat ek ook hier aanspreek, is die manier waarop Metz teologie bedryf. Selfs sy boeke (na Christliche Anthropozentrik) bestaan uit versamelings artikels wat in die meeste gevalle teruggaan op voordragte. Selde of ooit word 'n argument tot in sy volle konsekwensies deurgetrek. Dit is asof ' $n$ mens by die lees van die tekste met plakkate te doen het, elkeen vir 'n ander geleentheid gemaak, met die doel om treffend te wees, om op te val, om die gewone gang van sake te onderbreek. Dit is nie toevallig so nie. Metz verstaan sy teologie as korrektief, en enige sweem van heelheid, van antwoorde gee, van stelligheid, verdink hy daarvan dat dit die skynheiligheid van die bestaande bevestig. Metz bedryf teologie as vraag en nie as antwoord nie. Van sy artikels bestaan letterlik net uit 'n reeks vrae. Die probleem is dan hoe 'n mens sistematiseer waar daar geen sisteem mag wees nie. Is daar te midde van al die wendinge in Metz se teologiese denkweg, die pluraliteit van aksente, die invoer en laat vaar van begrippe, te midde van alle diskontinuiteit wel te praat van 'n metode? Waar kom hierdie metode vandaan? Wat wil Metz daarmee?

Hier word dus 'n soort "Op weg na die Politieke Teologie" onderneem. Die ontwikkeling van Metz se denkweg word beskryf en die wisselings word gekoppel aan sy wisselings van teologiese en filosofiese gespreksgenote. Ek wys dat Metz egter nie die te verwagte wisseling van Adorno na Habermas voltrek nie, en gebruik die motivering hiervoor as geleentheid om die sentrale kategorieë van die "volwasse" Politieke Teologie kortliks te beskryf: die verhouding tussen verlossing en bevryding; die subjek van die geloof; teodisee, herinnering, vertelling en solidariteit; en die primaat van die praksis. Ten slotte probeer ek Metz se metode beskryf in terme van die metode van die negatiewe dialektiek. Deurgaans wys ek op die konsekwensies van 'n bepaalde denke vir 'n begrip van concupiscentia, aangesien dit my oortuiging is dat hierdie begrip die (dikwels onuitgesproke) sleutelbegrip bly in al die stadiums van Metz se teologiese denkweg (vgl Hofmeyr 1997).

Die artikel beslaan twee dele. In hierdie eerste deel word uitvoerig stilgestaan by Metz se sogenaamde transendentale fase, toe hy as belowende student van Karl Rahner meegewerk het aan dié se projek om die skolastiese teologie te herformuleer in die kategorieë van die twintigste eeuse antropologie. Die primêre filosofiese gespreksgenoot is Heidegger. In 'n ander artikel sal ek aan die oorgang na 'n "teologie van die wêreld" 
en uiteindelik na die "nuwe" Politieke Teologie aandag gee, oorgange wat voltrek word in gesprek met Ernst Bloch, Theodor W Adorno en Walter Benjamin.

\section{DIE BEGIN}

\section{1 'n Enkele biografiese gegewe}

Die impuls om teologie as biografie en selfs as outobiografie te bedryf, het oorspronklik onder andere van Metz uitgegaan (kyk Metz 1977:195-203). Dit hang saam met sy oproep dat sisteembegrippe deur subjekbegrippe vervang moet word, wat daarop neerkom dat Christene en veral Christelike teoloë opnuut moet leer hoe om "ek" te sê (Metz 1984:383). Daarom word hier begin met 'n enkele biografiese gegewe.

In die doodsnikke van die Tweede Wêreldoorlog word die sestienjarige skoolseun uit Beiere in 'n uniform geforseer en saam met sy kamerade gestuur om die Amerikaners te gaan keer wat Duitsland reeds oor die Ryn binnegeval het. Een nag stuur die kompanie-bevelvoerder hom na die hoofkwartier van die battaljon. Toe hy die volgende môre deur brandende dorpe en woude sy weg terugvind tot by sy makkers, kry hy net dooies. "Ich konnte ihnen allen nur noch ins tote Antlitz sehen. Und bis heute erinnere ich nichts anderes als einen lautlosen Schrei, in dem vermutlich all meine Kindheitsträume und das, was man 'kindliches Vertrauen' nennt, zerfallen sind” (Metz 1994:305).

Met hierdie ervaring en hierdie herinnering - wat hy 'n gevaarlike herinnering noem (Metz 1977:77-86) - is hy nie later na 'n sielkundige nie, sê hy, maar hy is daarmee die kerk in: "Nicht, um mir von ihr diese Erfahrung und diese Erinnerung ausreden zu lassen, sondern um mit ihr an Gott zu glauben und von Gott zu reden” (Metz 1994:306). Vandaar die onrus en die onversoendheid in sy teologiese taal binne 'n teologie vir mense wie se kinderdrome vernietig is.

\subsection{Gebed van 'n jong priester}

Metz se vroeë tekste bestaan uit wetenskaplike artikels sowel as "populêre" religieuse lektuur - preke, gebede en meditasies. En van die begin af word die meer populêre “vroomheidstekste" gekenmerk deur onrus, 'n bewussyn van pyn en smart. So is daar die 
gebed "Herr, wir danken Dir für diese Kirche" uit 1956 wat wys dat die verlange na die nie-beskikbare, na die "ander" van die begin af daar was (Metz 1956).

Die mensbeeld wat in hierdie gebed na vore kom, is van vreemdelinge en swerwers op aarde. Daar word verwys na die "dunkle Not unserer Herzen" wat gestil word as die brood van Christus se lewe geëet word. Die aardse toestand word in metafore beskryf, 'n toestand, so word geïmpliseer, wat aanleiding gee tot die skep van valse hemele, en wat in die kerk, sonder hierdie valse hemele, op die altaar gelê moet word: "die stürzende Schwere unseres eigenen Lebens", en ook al die "harte und wilde Not unserer Brüder und Schwester." Daar word gepraat van die naamlose verlange van ons onbegrensde harte, en hulle verborge ongeduld met ons aarde. Die verlange moet in die kerk uitgegiet word - dis die plek daarvoor. Die verlange moet as verlange geld, maar op die regte plek want die tendens is juis om bedrieglike hemele op te rig, hemel op aarde.

Die gebed is ook 'n dankgebed vir die geheim van die goddelike liefde - dat Christus, die heilige, die onsterflike, in die verganklike kom woon het. Die geborgene het hom tuis gemaak by diegene sonder 'n vaderland. Die wêreld is geen tuiste ("Heimat") nie, maar omdat die mens weet van 'n tuiste, verlang hulle daarna. Die drang na 'n vaderland laat hulle allerlei drome agternaloop. Maar dis alleen maar drome. Te midde hiervan, bid Metz (1956:322): "Laß uns dann noch einmal wissen, daß Du da bist, daß wir zu Dir kommen können, kaum Geahnter und doch überall Gesuchter, daß wir Dich finden können, nebenan, mitten unter den Fassaden unserer Welt - Dich, den Weg und die Wahrheit unseres Lebens. Amen.”

Die kerk is, uiteindelik, die bastion van Christus se "Landnahme" en hierdeur het die hemelse hom in die aarde veranker. Hierdie deel van die gebed bevat die spits van die Christologiese inhoud daarvan. Terselfdertyd is dit ekklesiologie. Die woord "fassade" kan op 'n gewone gebou wys, maar tog het dit iets van "maar net 'n fassade", met ander woorde, dit kan ook wys op iets bedriegliks. Die fassades van hierdie wêreld is dan eintlik leeg, gee nie die geborgenheid wat hulle belowe nie - steeds: die wêreld is ons woning nie. Intussen het een van hierdie fassades as ' $t$ ware 'n venster (of 'n oop deur) op die ewigheid gekry, die kerk. Want die kerk berg die teenwoordigheid van Christus op aarde, die ewigheid wat toeganklik geword het. Christus is te vind, langsaan. Die Christologie is hier die een van "klop, en vir julle sal oopgemaak word; soek, en julle 
sal vind". Hierdie gebed, en die gebedsgeloof van Metz wat hierin tot uitdrukking kom, deel dus die gees van die gebedsgeloof van Jesus self.

Die laaste deel van die gebed is aan Maria gerig, en daarin staan 'n betekenisvolle metafoor: "Breite aus Deine Hände über alle, für die Du unter dem Kreuze standest und die heute diesem Kreuze fernestehen. Rufe sie heim ... in die Gezelte Deines Sohnes". As 'n mens hier in die eerste plek aandag gee aan die plek onder die kruis as 'n woonplek, kan die dwaalweë van die mense, waarvan dikwels sprake is, in verband gebring word met die vér weg wees van hierdie plek onder die kruis.

Hier tree die tema van Metz se teologie na vore: die verlange na God te midde van die Godverlatenheid. Die onvermoë om in die verlange te volhard is met concupiscentia in verband te bring. Dit is die onvermoë om die kruis as die modus van God se aanwesigheid in hierdie wêreld te voltrek.

\subsection{Heidegger en die probleem van die metafisika}

\subsubsection{Metz se aanvanklike Heidegger-resepsie}

Metz se akademiese loopbaan begin met 'n filosofiese promosie onder E Coreth te Innsbruck oor Heidegger en die probleem van die metafisika (Metz 1953). In hierdie geskrif is daar minder van die onrus te bespeur en meer van die sekerheid.

Metz se spesifieke tema is Heidegger se oordeel dat Nietzsche se denke, wat uitmond in die woord "God is dood", die voltrekking is van die Westerse metafisika. Dit gaan dus oor Heidegger se beroemde uitspraak dat die metafisika in sy wese Nihilisme is omdat die syn daarin vergete geraak het. Metz dink egter anders oor die transendensie as Heidegger, en sy metafisiese vooronderstellings maak dit vir hom onmoontlik om die ware radikaliteit van Heidegger se radikalisering van die vraag na die syn tot die vraag na die sin van syn, in te sien (vgl Caputo 1987).

Die voorrang van die fenomenologiese metode by Heidegger word genoodsaak deur Kant se beperking van die suiwer rede. Die sin van die syn as syn kan nie suiwer refleksief-argumentatief geken word nie. Metz deel nie in hierdie vooronderstelling nie; sy teenargument is 'n kernagtige opsomming van Rahner se Hörer des Wortes: die synsvraag is, soos by Heidegger (1977:6-8), in die eerste instansie (formeel) 'n menslike vraag en deel dus in die wesenskarakteristieke van menslike vraagstelling - dat dit 
deelneem aan dit waarna gevra word, die syn. Tweedens (modaal): die synsvraag geskied noodwendig, want dit behoort tot die wese van die mens om te vra. En omdat dit noodwendig geskied, is dit rasioneel verstaanbaar. Alle noodwendige vraagstelling berus naamlik op die een of ander orde wat ingesien kan word. Die resultaat is dat die syn as dit wat 'n rasionele, verstaanbare vraag apriories moontlik maak, self ook rasioneelverstaanbare syn is. Derdens (kousaal): van die noodwendigheid en absoluutheid van menslike vraagstelling word 'n egte transendensiebegrip afgelei. Juis omdat dit noodwendig en absoluut is, kan die vraag nie sy grond hê in die (juis op grond van die noodwendigheid van die vra) kontingente syn van die mens nie (Metz 1953:16-17 voetnoot $14 a)$.

Dit is presies hierdie argument wat Metz (1977:142-145) later as toutologies sou tipeer en kritiseer, maar in 1953 sien Metz nog nie die probleem nie en antwoord hy Heidegger se bevraagtekening van die metafisika met die analogia entis wat beteken dat syndes eners is in verskeidenheid.

Die syn van die synde is vir Metz die ontologiese formele grond van die eenheid van alle enerse syndes. Die een syn kom analoog voor in syndes. Die manier waarop die syn "in" syndes "is", is as analoog ook gegradeer. Die identiteit tussen logos en on verskil dus afhangende van die graad van syn wat 'n synde toekom. Die mens beweeg op 'n "dem Menschen eigentümlichen Analogiestufe", en dit gaan daaroor om die ontologiese struktuur hiervan te analiseer (Metz 1953:18). Die menslike Dasein bly maar 'n vlak van die oorspronkliker analogie, al het dit ontologiese prioriteit. Dit beteken dat die ontologiese metafisika, deur mense bedryf, egte grense het. Dit staan in die dinamiese spanning tussen konkretisering en abstraksie, die materiële en die formele, die ontiese en die ontologiese (Metz 1953:22).

Op grond van die "egte grense" van menslike kennis is daar steeds sprake van God as Geheimenis. Maar fundamenteel is alles in orde. Die nagkant van die bestaan kan verklaar word in terme van die onvolmaakte synsvlak waarop die mens beweeg eindigheid (metafisies) en materialiteit (fisies). Die strekking van Heidegger se kritiek op die metafisika, dat die daarin verborge sin van die syn, die ontwerp van sin wat daarin heers, nie net verborge is nie, maar ook nietig, gaan eintlik by Metz verby. Die "sinskatastrofe" (Metz 1977:144) van die Naziheerskappy en die einde daarvan vind nog nie weerklank in sy akademiese werk nie. 


\subsubsection{Heidegger se vraagstelling}

\subsubsection{Die vraag na die grond}

Kant (1976:A vii-viii) het reeds aangedui dat die waarom-vraag as vraag na die grond fakties altyd daar is. In sy opstel "Vom Wesen des Grundes" wil Heidegger (1976) nie redes gee vir die faktisiteit van die waarom-vraag nie, hy vra nie na die waarom van die feit van die immerteenwoordige waarom-vraag nie, maar na die transendentale moontlikheid van hierdie vraag hoegenaamd. Hy antwoord: dit is juis die meer aan moontlikhede in die wêreldontwerp wat die waarom laat ontspring in daardie Dasein wat ook en gelyktydig geworpe is in dit wat is en daarom slegs bepaalde moontlikhede as werklike moontlikhede het. Omdat ontwerp en geworpe-wees in die transendensie saam hoort, is die ontspring van die waarom transendentaal noodwendig: waarom so en nie anders? Waarom dit en nie dat? Waarom hoegenaamd iets en nie niks nie? (Heidegger 1976:65).

In hierdie waaroms is egter reeds 'n voorbegriplike voorverstaan aanwesig van wat-wees, hoe-wees en syn (niks). Die waarom-vraag kan dus eers ontstaan op grond van 'n "synsverstaan". En daarmee is die oer-antwoord op alle waarom-vrae reeds gegee in die moontlikheidsvoorwaarde van die vraag: "Das Seinsverständnis gibt als vorgängigste Antwort schlechthin die erst-letzte Begründung" (Heidegger 1976:65). Die voorverstaan as synsverstaan wat in die waarom-vraag reeds teenwoordig is, die waarom-vraag wat wesenlik voortvloei uit transendensie as eenheid van meer aan en beperking tot (werklike) moontlikhede, gee dus as eerste ("vorgängigste") antwoord as sulks die "erstletzte" begronding. Dit is dus die transendensie wat, as dit wat hierdie synsverstaan laat ontstaan, daarin as sodanig begrondend is.

Eers in die lig van die synsverstaan (denkvorm by Metz) kan dit wat is, openbaar word as en hoe dit is wat dit is. Laasgenoemde is die ontiese waarheid met betrekking tot dit wat is, waarin die ontologiese waarheid altyd meespreek omdat dit die "is" bepaal. Die ontiese waarheid is dus altyd reeds deursuur met die "Begründen". Daarom moet alle ontiese ontdekking en ontsluiting "begrondend" wees, met ander woorde, dit moet sigself regverdig of bewys. So is die transendensie die oorsprong van die "Gründens".

Heidegger sê dit is kenmerkend van die metafisika dat dit 'n ontiese grond vir ontologie voorveronderstel. Met ander woorde, dit laat die sin van syn bepaal word 
vanuit die perspektief van 'n bepaalde synde, naamlik God. Hierdie hoogste synde word nie verder na sy syn bevra nie, of die sin van sy syn word nie bevraagteken nie. Heidegger sny hierdie verbinding af. In "Vom Wesen des Grundes" stel hy die grondvraag van die filosofie: "Warum überhaupt etwas und nicht nichts?" (Heidegger 1976:64). Die grond is die antwoord op die waarom in hierdie vraag, die daarom. Hier word gevra na die voorkeur van die syn bo die nie-syn, die niks.

Waar die metafisika 'n hoogste synde geponeer het, sê Heidegger is daar niks. Waar daar 'n vaste grond veronderstel is, gaap 'n afgrond. Dit was juis op grond van hierdie as vaste grond gewaande hoogste synde dat die mens in die Westerse metafisiese geskiedenis magtig geword het. Vryheid was vryheid tot magtigheid. Heidegger verstaan nou die transendensie in die sin van vryheid tot die grond, as afgrond en daarmee word ook die wese van die geworpenheid geraak. Die gelyktydigheid van ontwerp en geworpenheid laat hom van die onmag van die vryheid praat. Die onmag van die eindige vryheid bepaal die syn van Dasein as sodanig (Heidegger 1976:70).

By Heidegger word die syn van Dasein nie meer as bestendige anwesigheid gedink nie, maar as radikale eindigheid. Hy wil die wese van die eindigheid van Dasein opklaar vanuit die synskonstitusie van Dasein: "Ursprünglicher als der Mensch ist die Endlichkeit des Daseins in ihm" (Heidegger 1991:229). Die analise van die synskonstitusie van Dasein mond uiteindelik uit in die transendentaal noodwendige vraag: waarom is daar iets en nie maar niks nie? Gegewe die oerbesluit wat aan die begin van die geskiedenis van die metafisika geval het, moes hierdie vraag altyd beantwoord word in verwysing na die hoogste synde en so is die afgrond verdoesel. Volgens Heidegger is dit juis die vryheid wat die afgrond laat oopbreek in die grondende transendensie. Die wêreldontwerpende Dasein moet in die proses om dit wat is te bowe te gaan, ook sigself te bowe gaan "um sich aus dieser Erhöhung allererst als Abgrund verstehen zu können" (Heidegger 1976:70).

Die wending "grond-afgrond" moet hier verstaan word as 'n aanspeling op dieselfde soort wending in "God-afgod". Elders vertaal Heidegger transendensie met "oorkom" (vgl Pöggeler 1975:172). Dasein moet homself as grond oorkom om homself as gewaande grond as afgrond te verstaan. In hierdie verband moet na Heidegger se tipering van die metafisika as Nihilisme verwys word. 


\subsubsection{Die metafisika as Nihilisme}

Die syn gedink as bestendige teenwoordigheid is altyd voorhande en dus binne die greep van die rede; 'n rede wat volgens die epistemologie van representasie (voorstelling) opereer. Dit kan dus aan die "lis van die rede" toegeskryf word dat die syn gedink is as bestendige aanwesigheid. So word die grondhouding van die mens ten opsigte van die werklikheid waarderend (waarde-toekennend), subjektiverend, berekend, beheersend (Schoeman 1978:123; vgl ook Shapiro 1984:215-217). "Measurement began our might," sê Yeats (aangehaal by Young 1992:128).

Teen hierdie agtergrond is Heidegger se gaan van 'n nuwe denkweg begryplik, sy kweek van 'n nuwe denkhouding, 'n denke "gegen die Werte": want sodra aan 'n synde 'n waarde toegeken word, word hierdie synde juis van sy waarde beroof. Heidegger (1976:179-180):

...durch die Einschätzung von etwas als Wert wird das Gewertete nur als Gegenstand für die Schätzung des Menschen zugelassen. Aber das, was etwas in seinem Sein ist, erschöpft sich nicht in seiner Gegenständlichkeit, vollends dann nicht, wenn die Gegenständlichkeit den Charakter des Wertes hat. Alles Werten ist, auch wo es positiv wertet, eine Subjektivierung. Es läßt das Seiende nicht: sein, sondern das Werten läßt das Seiende lediglich als das Objekt seines Tuns - gelten. Die absonderliche Bemühung, die Objektivität der Werte zu beweisen, weiß nicht was sie tut. Wenn man vollends "Gott" als “den höchsten Wert" verkündet, so ist hier und sonst die größte Blasphemie, die sich dem Sein gegenüber denken läßt.

Dit is ook in hierdie verband dat Heidegger se uitspraak verstaan moet word dat die metafisika in sy wese Nihilisme is. Dit word by Nietzsche volledig duidelik. Wat beteken Nihilisme vir Nietzsche? Die nihil in Nihilisme beteken nie nie-syn nie. Eerstens beteken dit on-waarde ("Un-Wert"). Die lewe word on-waarde in die mate dat dit negeer, gedevalueer word. Hierdie devaluering voorveronderstel altyd 'n fiksie en deur middel van hierdie fiksie vervals en devalueer die mens, meet 'n mens die lewe aan iets (vgl Deleuze 1985:161-162). 
Diese reine Fiktions-Welt unterscheidet sich dadurch sehr zu ihrer Ungunsten von der Traumwelt, daß letztere die Wirklichkeit widerspiegelt, während sie die Wirklichkeit fälscht, entwertet, verneint. Nachdem erst der Begriff "Natur" als Gegenbegriff zu "Gott" erfunden war, mußte "natürlich" das Wort sein für "verwerflich", - jene ganze Fiktions-Welt hat ihre Wurzel im Haß gegen das Natürliche (- die Wirklichkeit -), sie ist der Ausdruck eines tiefen Mißbehagens am Wirklichen... Aber damit ist alles erklärt. Wer allein hat Gründe, sich wegzulügen aus der Wirklichkeit? Wer an ihr leidet.

(Nietzsche 1964b:204-205)

Dit blyk hieruit dat die metafisika van meet af aan eintlik teodisee was. Die gevolg van die devaluaring van die werklikheid is in elk geval dat die lewe in sy geheel irreëel word en as skyn voorgestel word. As skyn is dit met betrekking tot die syn onwaardig. Die voorstelling van 'n bo-sintuiglike wêreld, 'n ander wêreld met al sy vorme (God, wese, die goeie, die ware), kortom, van waardes wat bo die lewe staan, is konstitutief vir die fiksie. En die gevolg is die ontwaardiging van die lewe, die negering van hierdie wêreld. Die gevolg is nie van die fiksie te skei nie, aangesien die fiksie gegrond is in ' $n$ wil tot negering en ontwaardiging. Die wil tot negering is Schopenhauer se "Nicht-wollen". Dit is as nie-wil 'n wil tot niks. Maar die wil bly, desnieteenstaande: "aber es ist und bleibt ein Wille!..." (Nietzsche 1964a:412).

So beteken nihil in Nihilisme die negering as 'n kwaliteit van die wil tot mag. Volgens Deleuze (1985:161) beteken Nihilisme dus by Nietzsche primêr: "der vom Leben angenommenen Un-Wert, die Fiktion höheren Werte, die ihm diesen Un-Wert verleihen, der Wille zum Nichts, der sich in diesem höheren Werten äußert."

Nihilisme beteken vir Nietzsche ook iets anders, wat met die eerste saamhang, daarop reageer. Hierdie reaktiewe Nihilisme spruit voort uit die eerste, negatiewe Nihilisme. Op die ontwaardiging van die lewe deur die hoër waardes word gereageer deur die hoër waardes self te negeer. Hierdie waardes is ook niks. Daar is geen hoëre waardes nie, maar die lewe word nog altyd gesien soos dit in die lig van die steeds heimlik as geldig veronderstelde hoër waardes verskyn. Die lewe bly onwaarde. Die ware syn is nie, maar die lewe bly blote skyn, sonder doel, op pad na niks (Deleuze 1985:162). 
Heidegger sluit by Nietzsche se negatiewe Nihilisme aan. Die Nihilisme is nie in die eerste plek geleë in die verlies van waardes nie (reaktiewe Nihilisme), maar bestaan eerder daarin dat die syn hoegenaamd verstaan is in terme van 'n hoogste waarde (Schoeman 1978:121). Daarmee is in die metafisiese tradisie die vraag na die syn self verdring, of is dit vergeet. Daarom: synsvergetelheid. Die synsvergetelheid in die metafisika is die eintlike grond van die Nihilisme: "Das Sein selbst bleibt in der Metaphysik wesensnotwendig ungedacht. Die Metaphysik ist die Geschichte, in der es mit dem Sein selbst wesenhaft nichts ist: Die Metaphysik ist als solche der eigentliche Nihilismus" (Heidegger 1961:350).

Alfred Jäger (1978) het in 'n uiters deeglike studie sorgvuldig aangetoon dat dit veral Heidegger se bestudering van Schelling was wat hom die waarheid van die metafisika as onwaarheid laat sien het. Aan die hand van Schelling se bepaling van die syn probeer Heidegger (1971:204) om die wese van die ganse metafisiese tradisie te begryp. Dit wat vir Schelling en die metafisika tipies is, vind Heidegger in die bepaling van die syn as wil, grond en eksistensie. Dit is hoe Schelling die syn verstaan en wel asof vanselfsprekend. Net so vanselfsprekend gee Schelling die volgende predikate aan die syn: "Grundlosigkeit, Einigkeit, Unabhängigkeit von der Zeit, Selbstbejahung" (Jäger 1978:325).

Heidegger problematiseer egter al hierdie sogenaamde predikate van die syn, veral "Grundlosigkeit". Vir Schelling beteken "Wollen" om grondlose grond van sigself te wees. Dit is ook sy Godsbegrip. Daarom kan Heidegger (1971:212) van Schelling sê: "Schelling denkt metaphysisch, onto-theologisch, aber in der höchste Vollendung." "Wollen" word dus deur Schelling toegevoeg aan die lang lys van name wat die grond al in die geskiedenis van die metafisiese denke gehad het, van die Grieke tot by Nietzsche. Gemeenskaplik aan al hierdie name vir die grond, en dus vir die syn, is dat dit die syn tipeer as die reeds aanwesige, die bestendige teenwoordigheid. Die Grieke het reeds alles gesê deur die syn (grond) met die woord Hypokeimenon aan te dui. In Latyn is dit vertaal met "das sub-iectum. Jedes Seiende ist als Seiendes sub iectum (sub-stans). Dieser Satz gilt für alle Metaphysik von Plato bis Nietzsche" (Heidegger 1971:221).

Schelling, en ook Hegel, is dus by die lys ingesluit. Nie een gaan die metafisika te bowe nie, want albei gee maar verskillende name vir dieselfde, dink op verskillende maniere die absolute as "Subjektität", sonder om te vra wat "grondloosheid" sou beteken 
(Jäger 1978:327). Heidegger (1971:219) se kritiek op die Duitse Idealisme is op hierdie punt gerig en Idealisme (Schelling, Hegel) en Nihilisme (Nietzsche) staan dus vir Heidegger in die nouste verband. Hegel se "Wille des Wissens", Schelling se "Wille der Liebe" en Nietzsche se "Wille zur Macht" het as gemeenskaplike dat elk op sy eie manier net een ding wil hê: "sich selbst". Daarom, sê Heidegger (1971:323), is Schelling en Hegel se worsteling om te kom tot 'n begrip van die absolute blote skyn. Slegs skynbaar word na die syn gevra “während doch gerade das 'Sein' längst entschieden ist" en wel as die "unbedingte Subjektivität".

\subsubsection{Heidegger en Rahner/Metz}

Metz het Heidegger nie oral ewe reg verstaan nie. So sê hy byvoorbeeld dat Heidegger se syns - en waarheidsleer 'n dialektiese struktuur het, en dat hierdie struktuur 'n klassieke simptoom is van die poging om die syn in sy geheel suiwer vanuit die vlak van die menslike syn te ontwikkel. Syn en menssyn word gevolglik geïdentifiseer (Metz 1953:22). Heidegger (1976:58, voetnoot 59) sê uitdruklik hy vra na Dasein en sy tydlikheid slegs ter wille van die vraag na die syn, en dat Dasein se bevoorregte posisie nie dui op 'n subjektivering van alle syndes nie. Volgens Pöggeler (1975:171) is Heidegger se denke deur 'n afgrond geskei van daardie metafisiese denke wat meen om deur middel van 'n transendentale refleksie die "gradering" van syndes met betrekking tot die syn te definieer. Dit beteken natuurlik, in terme van Pöggeler se tese, dat daar 'n afgrond behoort te gaap tussen Rahner en die vroeë Metz se metafisika en Heidegger se denke.

By nadere ondersoek blyk dat Rahner wel die gradering van die syn van Thomas en uit die metafisiese tradisie oorneem. Soos gesien, bepaal Rahner (1957:74-75), soos Heidegger, die mens wesenlik as vraag. Die vraag na die syn in sy geheel gee uitdrukking aan 'n reeds bestaande kennis van die syn. Kennis van 'n synde in die hier en nou berus op sintuiglikheid. Die vraag is hoe a priori en a posteriori kennis met mekaar verbind word. Vir Rahner (1957:79) gaan dit oor die verstaan van “der innern Möglichkeit der Einheit von Sinnlichkeit und Intellekt". Hierdie eenheid lê in die identiteit van syn en ken. In die ken van dinge in die hier en nou word vooruitgegryp op die syn in sy geheel. Die modus van hierdie vooruitgrype is die vraag. Wat affirmeer word in die uitspreek van oordele oor syndes is dus die bevraagbaarheid van die syn in sy geheel. Daarom die gevolgtrekking, en daar moet gelet word op die konjunktief wat moontlikheid 
uitdruk: "Sein ist Erkannt-seinkönnten" (Rahner 1957:81). In Hörer des Wortes lui die volledige definisie: "Das Wesen des Seins ist Erkennen und Erkanntheit in ihrer ursprünglichen Einheit, mit anderen Worten Bei-sich-sein, Gelichtetheit" (Rahner 1963:55). Rahner se argument herinner aan dié van Maréchal wat sê: "(t)o affirm of God that he is possible is the same as to affirm that he exists, since his existence is the condition of every possibility" (aangehaal by Sheehan 1987:87). Die vraag na die syn in sy geheel impliseer noodwendig die bevestiging van die fundamentele kenbaarheid en aprioriese gekendheid van die syn: "Wenn der Fragende nach Sein fragt, muss er Sein 'sein', weil er in der Frage schon von Sein weiss und er doch von Sein nur wissen kann ..., insofern er das Gewusste selber ist" (Rahner 1963:64).

Die aandag is gevestig op Rahner (1957:81) se gebruik van die konjunktief in die sin "Sein ist Erkanntseinkönnten". Die identiteit van syn en ken, die insig dat kenbaarheid 'n ontologiese bepaling van die synde is, gaan gepaard met 'n grondoortuiging van Rahner (1957:84) se kennismetafisika, dat die syn onfikseerbaarheid is: "Damit, daß sich Sein als die vorgängige und ursprüngliche Einheit von Erkennen und Erkanntem bestimmte, gerät dieses Sein selbst in eine wesentliche Unfixier-barkeit." In die vraag as modus van kennis word slegs die vraagbaarheid van die syn geken. Die feit van die vraag wys dat syn is. Wat syn is, is ongefikseerd. Al wat van syn gesê word is dat daarna gevra word.

En tog is syn reeds met kennis geïdentifiseer. Word die vraaglikheid van die syn nie daardeur opgehef nie? Of hef die bepaling van die syn as vraaglik die identiteit van syn en ken op? Rahner (1957:85): "Der Fragenmüssende ist Sein, weil er im Fragen nach dem Sein schon beim Sein ist, und ist es doch nicht, weil er noch nicht so bei dem Sein im Ganzen ist, dass dieses Beim-Sein-Sein fragloser Besitz des Seins im Ganzen wäre.”

Dit is duidelik waarheen Rahner op pad is: syn en ken is een, maar nie volkome in die mens nie. Tog is syn en ken tot ' $\mathrm{n}$ mate een in die mens. Een van die formulerings wat Metz met Rahner se uitdruklike toestemming in sy hersiening van Hörer des Wortes ingevoer het, is die tipering van God as die synde van absolute "Seinshabe" (vgl. Rahner 1963:11-12). Die mens as 'n bepaalde synswyse is dus die synde van relatiewe "Seinshabe".

Daarmee voer Rahner, hierin soos Maréchal 'n getroue volgeling van Thomas, die konsep van die gradering van die syn in sy argument in. Syn is "Bei-sich-sein", of, 
vertaal in 'n epistemologiese kategorie, self-deursigtigheid. Die graad van die selfdeursigtigheid is direk eweredig aan die synsmagtigheid, die graad waarin syn 'n synde toekom, 'n synde syn "het". Omgekeerd geld dus dat die mate waarin 'n synde selfrefleksief is, tot sigself kan terugkeer, die mate van "Seinshabe" daarvan verteenwoordig.

Die vraag is of Heidegger se kritiek op Hegel en Schelling ook die transendentale Thomisme tref. Word slegs skynbaar na die syn gevra? Het die besluit ook hier lankal geval dat die syn niks anders is nie as ongebreidelde subjektiwiteit? Metz se aanvanklike kritiek op Heidegger geskied vanuit Rahner se posisie, en ontken dat die syn in die Thomistiese metafisika vergete geraak het. Sy latere kritiek op Rahner maak nie meer gebruik van Heidegger se terminologie nie, maar dit gaan oor dieselfde probleem.

Die probleem wat Heidegger aanspreek, gaan in hierdie vroeë stadium van Metz se denke eintlik aan hom verby, aangesien hy op grond van die transendentale Thomisme te seker is van sy saak. En as hy toenemend van die probleem bewus word, is dit nie meer in gesprek met Heidegger nie. As 'n teoloog wat uiters sensitief is vir die geestesstrominge van sy tyd (hier die 1960s) registreer Metz ook hoe Heidegger se ster ondergaan namate Bloch se ster opkom. Maar tot die eintlike vraagstelling dring Metz eers deur na sy blootstelling aan Adorno.

Hierdie probleem kan so geformuleer word: as in die metafisika God gedink word as die absolute in terme van die volkome aktualisering sonder enige res aan moontlikheid, en dus as die absoluut selfgenoegsame, is dit dan nie maar ' $n$ projeksie van die menslike subjektiwiteit tot in die absolute nie? Dit is onder andere waarna die beskuldiging van toutologie in Metz (1977:145) se latere Rahner-kritiek verwys.

\subsection{Die wending na die mens}

Metz promoveer in die teologie onder die leiding van Rahner met 'n dissertasie getiteld Christliche Anthropozentrik: Über die Denkform des Thomas von Aquin (1962). Die begrip "denkvorm" het by Metz 'n betekenis wat al nader is aan Heidegger se "sin van die syn". Metz stel die tese op dat die "epogale wending" in die geestesgeskiedenis van die Weste, waaruit die "Neuzeit" (hier vertaal met Moderne (hoofletter)) ontwikkel, reeds by Thomas plaasvind. Die Thomistiese denkvorm is antroposentries, dit wil sê aan die "subjektiwiteit" georiënteer. Daarteenoor was die Griekse denke formeel (dit wil sê 
ontologies) kosmosentries (Metz 1962a:45-47). Belangrik is dat dit - volgens Metz (1962a:124-125) - juis die gees van die Christendom is wat by Thomas die Griekse filosofiese denke, in sy Aristoteliese gestalte, "aufhellt und epochal gewandelt weiterführt".

Drie fassette van Metz se argument kan onderskei word. Eerstens is daar die onderskeid wat Metz tref tussen denkvorm en denkinhoud. Tweedens is daar sy tese dat Thomas se denkvorm antroposentries is en dat hy so die Moderne inlui. En derdens is daar sy tese, die sogenaamde sekulariseringstese, dat dit die gees van die Christendom is wat in die antroposentriese denkvorm deurbreek en dat die Moderne dus uit die gees van die Christendom ontstaan. Metz se Thomas-interpretasie self word nie hier beoordeel nie. Die feit dat die oorgaan na die Moderne volgens Metz by Thomas plaasvind, het wel vir die nuwe Politieke Teologie 'n sekere relevansie, in so verre die laat-Middeleeue met die opkoms van die burger in verband gebring kan word, en dus met die etablering van die "burgerlik/Christelike" subjek (vgl Vattimo 1993:44-60).

\subsubsection{Denkvorm en denkinhoud by Metz: Die formele en materiële verstaans- prinsipes}

Die belangrikste resultate van Metz se analise, soos dit hier geïnterpreteer word, is: die "waarop" van die Vorgriff staan in 'n noue verband met die "waarmee" van die denke; denkvorme is histories; en die ontologiese differensie beteken dat denkvorme nooit suiwer denkinhoud kan word nie. Reeds in sy werk oor Heidegger het Metz (1953:22) aan die metafisika die taak gegee om die dinamiese spanning tussen konkretisering en abstraksie, die materiële en die formele, die ontiese en die ontologiese te konseptualiseer. In Christliche Anthropozentrik word die spanning in eenheid wat bestaan tussen denkvorm en denkinhoud ondersoek. Op grond van die analogie van die syn wat ook hier vooronderstel is, word onderskei sonder om te skei. Daar is eenheid in verskeidenheid en wel onder die primaat van die denkvorm.

Metz (1962a:25-26) tipeer "verstaan" as "Prinzipienforschung". Om te verstaan beteken dus om te vra na die eenvoudige prinsipe van 'n denke wat die veelheid van begrippe en uitsprake saambind. Daar is twee sulke beginsels, 'n formele en 'n materiële. 


\subsubsection{Die materiële verstaansprinsipe}

Metz verduidelik die materiële verstaansprinsipe deur na 'n voorbeeld te verwys: die verskillende begrippe en uitsprake van 'n bepaalde denker se antropologie is die uitdrukking van hulle gemeenskaplike herkoms uit 'n voorafgaande sinsontwerp van daardie antropologie in sy geheel. Die geheel (sinsontwerp) is teenwoordig in alle deeluitsprake. Hierdie sinontwerp noem Metz (1962a:27) 'n voorafgaande sin- en uitspraakeenheid waarin sin en uitsprake mekaar wedersyds verhelder. Die deelbegrippe en deeluitsprake ontspring aan die eenheid en die eenheid kom te voorskyn en word uitgedruk deur die begrippe en uitsprake.

\subsubsection{Die formele verstaansprinsipe (denkvorm)}

Die denkvorm gee aan die totaliteit van denke ' $n$ innerlike eenheid en vorm (Metz 1962a:30). Denkvorm is synsverstaan (Metz 1962a:30, voetnoot 6, 31). Die denkvorm betref dus die syns- en selfverstaan van die mens in totaliteit. Dit vorm die omsluitende horison waarbinne alles eers in aansyn geroep word. Die denkvorm is "vorm" in die sin dat dit die wesensbeskouing "vorm" of ontwerp waarbinne die denkinhoud eers sigbaar word vir wat dit is (Metz 1962a:33). Wat 'n bepaalde denke karakteriseer is nie primêr wat daarin gesê word nie, maar die horison waarbinne elke uitspraak altyd reeds staan. Of, soos Metz (1962a:34) dit kort en bondig saamvat: "nicht das, worüber nachgedacht wird, sondern das, womit nachgedacht wird" is wat denkvorm beteken. In denkvorm gaan dit dus oor 'n manier van dink ("Denk-ungsart") "unter dessen Dominanz alle Denkinhalte stehen" (Metz 1962a:46). Metz (1962a:47) gebruik ook die term aprioriese synsontwerp vir denkvorm: "Die Denkform oder das Seinsverständnis bezeichnet jenen apriorischen Seinsentwurf, von dem her alle inhaltliche (ontischen) Bestimmungen der Seienden getroffen werden bzw. in dem und von dem her alle Seienden in ihrem Seinsverhältnis erscheinen."

Anders gestel, met verwysing na die problematiek soos bedink deur Heidegger, wie se invloed op Metz se verstaan van denkvorm duidelik is: in denkvorm gaan dit oor wat aanvanklik by Heidegger die sin van syn as syn en later die waarheid van die syn heet. Die syn word eers bevra soos dit "daar" is in die besondere synde Dasein (Metz se materiële verstaansprinsipe). Die dele word op die geheel geprojekteer en van die geheel word teruggekom op die dele. Die synsverstaan wat so verkry word, word nou in 'n 
tweede projeksie geprojekteer op die doek wat die sin (waarheid) van syn heet. Die vraag is: Waarop geskied die tweede projeksie? Of, om die term van Heidegger te gebruik wat Rahner vir sy denke vrugbaar maak: waarop gaan die "Vorgriff"? Dit is die ontologiese vraag wat van die eerste, die ontiese vraag onderskei moet word.

Die Vorgriff definieer Rahner (1963:176) soos volg: "Der Vorgriff als solcher ist ... nicht ein apriorisches Wissen eines Gegenstandes, sondern der mit dem Wesen des Menschen gegebene und in diesem Sinn apriorische Horizont der Hinnahme eines aposteriorisch gegebenen sinnlichen Gegenstandes, die apriorische Bedingung der Erkenntnis einer aposteriorischen Erscheinung." Die Woraufhin van die Vorgriff is dus die horison waarbinne 'n sinlike objek geken word.

In denkvorm, sê Metz, gaan dit oor "waarmee" gedink word. Wat het die "waarmee" van die denke met die "waarop" van die Vorgriff te doen? Die uitsprake van 'n bepaalde denker (in hierdie geval Thomas), sê Metz (1962a:38), "werden nicht dadurch verstanden, daß sie sich rein objektivistisch in meinem vernehmenden Geist ausbreiten; sie werden verstehend nur vernommen, indem sie eintreten in den ihnen je schon entgegengebreitenden apriorischen Verständnishorizont meines Seins."

Lees 'n mens hierdie sin saam met Rahner se definisie van die Vorgriff is daar duidelik 'n noue verband tussen die "waarop" van die Vorgriff en die "waarmee" van die denke.

\subsubsection{Historiese verstaan}

'n Belangrike aspek moet nog genoem word. In Rahner se definisie van die Vorgriff is daar sprake van die aprioriese horison wat met die wese van die mens gegee is. Metz (1962a:35) lê meer klem op die historiese aard van verstaan. Dit gaan dan juis oor die wisseling van denkvorm wat die oorgang van een historiese epog na 'n ander konstitueer. Die denkvorm funksioneer wel apriories in 'n bepaalde epog. Dit is egter nie in sy besondere gestalte 'n struktuur wat deel is van die menslike natuur en dus altyd dieselfde was en sal bly nie. Aan die ander kant is dit ook waar dat 'n bepaalde denkvorm nie sommer oornag verander nie. 


\subsubsection{Ontologiese differensie}

Die belangrikste aspek is Metz se beklemtoning dat die formele prinsipe deur diegene wat daarmee dink nooit genoegsaam gereflekteer kan word nie. Die ontologiese differensie behels dat die denkvorm nooit suiwer denkinhoud kan word nie. Metz (1962a:36) haal vir Heidegger aan: Die denkvorm bly die "im allem Gesagten Ungesagte”. Die denkvorm is dit wat in alle uitsprake verdwyn, maar juis in die afwesigheid omvat en sentreer dit die ganse inhoud. Dit het met die hermeneutiese sirkel te doen wat Metz (1962a:36) soos volg beskryf: “der Gang des Verstehens bewegt sich im ständig spielenden Zirkel zwischen ausgesagtem Denkinhalt und der darin verborgenen Denkform." In 'n verdere verduideliking van die hermeneutiese sirkel gebruik Metz (1962a:36, voetnoot 13) self ook die woord "Vorgriff”: “[E]ine Aussage [wird] nur verstanden ... im Vor- bzw. Rückgriff auf das in ihr waltende Aussageprinzip, dieses [wird] aber wiederum nur in der Aussage selbst zugänglich...” Die blywende blinde vlek van die denke raak die subjekobjek verhouding.

\subsubsection{Subjek en objek}

Om histories te verstaan, behels volgens Metz (1962a:37) dat die subjek wat verstaan haarself in die verstaansproses volvoer. Dit gaan in historiese verstaan dus nie oor die blote nadink van wat reeds objektief voorhande is nie. Daarom is daar in menslike verstaan nie so iets soos "objektiwiteit" in die sin van suiwer van buite komende "aposterioriteit" nie. Metz (1962a:38) verstaan hieronder "horisonversmelting" as hy sê die uitsprake van 'n denker (Thomas) “werden verstehend nur vernommen, indem sie eintreten in den ihnen je schon entgegengebreiteten apriorischen Verständnishorizont meines Seins."

So geformuleer is die "subjektiwiteit" van historiese verstaan volgens Metz geen slegte subjektiwisme nie. Dit is die ontologiese moontlikheidsvoorwaarde van historiese verstaan. Dit kan nooit afgeskaf word nie. Dit kan slegs maar deur die subjek in ag geneem en verhelder word in die verstaansproses: “'Objektiv' verstehen heißt desbalb nicht: ohne 'subjektives (existentiales) Apriori' verstehen, sondern: aus einem mitvergewisserten Apriori verstehen" (Metz 1962a:38 voetnoot 16). In die hermeneutiek gaan dit oor die verheldering van die eie vooronderstellings, die eie sinontwerp wat as 't ware op die tafel geplaas word (vgl Gadamer 1986). Die beklemtoning van die maatskaplik 
bepaalde aard van die vooronderstellings verteenwoordig die oorgang van hermeneutiek na kritiese teorie wat Metz in die middel sestigs voltrek. Van Adorno het Metz (1977:62, voetnoot 34) geleer dat historiese ervaring nie bepaal word deur die smartlike dialektiek van subjek en objek te ignoreer nie, maar deur dit te verduur, daarin te volhard.

In Christliche Anthropozentrik beskryf Metz (1962a:53) die verhouding tussen subjek en objek so: 'Sein ist in seinem 'Ansich' (also 'objektiv') als - 'Subjektivität' gedacht." Hierdie uitspraak is ook vir Adorno geldig - as uitdrukking van die "denkvorm" van die burgerlike maatskappy. Die sin bly dus geldig binne die negatiewe dialektiek, en dit beteken dat dit aangevul word met sy omgekeerde: syn is in sy "Fürsich" (subjektief, dus) as objektiwiteit gedink. Syn, as subjektiwiteit gedink, is objektief. Dit beteken dat 'n denkvorm nie net met idees te doen het nie, maar ook met die konkrete wêreld. Ook die wêreld word vergestalt volgens die sinontwerp van 'n denkvorm. 'n Denkvorm is dus nie net van "literêre" tekste af te lees nie, maar van die wêreld as teks, as uitdrukking van 'n bepaalde ordeningsbeginsel. Die ontwykende aard van 'n denkvorm kragtens die ontologiese differensie, kan dus enigsins teengewerk word deur 'n dialektiese manier van dink wat die primaat nie aan die subjek gee nie, maar aan die objek. Dit is wat Adorno probeer doen en hierin volg Metz hom.

Die primaat van die objektiewe in 'n subjek-objek dialektiek beteken dat 'n sin soos die volgende steeds geldig bly: "Subjektivität ... bringt an sich selbst [das] Sein zur Erscheinung" (Metz 1962a:54-55). Die "syn" as sinontwerp bly steeds ontwykend, maar vind ook neerslag, onder andere in die menslike liggaam. Daarom kan Metz (1962a:55, voetnoot 22) in Christliche Anthropozentrik besluit ontologie is antropologie. By Adorno (1951) word ontologie die ontologie van die valse toestand. Dan word antropologie, in die woorde van Ulrich Sonnemann (1969:227), negatiewe antropologie "als Erschließung des Humanen aus seiner Verleugnung und Abwesenheit".

\subsubsection{Die antroposentriese denkvorm}

Die antroposentriese denkvorm is volgens Metz (1962a:49) aan die eiesoortige synsmodus van die mens georiënteer, en dit beteken aan die subjektiwiteit. Mens-syn het as model vir synsverstaan as sodanig die prioriteit bo die blote voorhandenheid van die wêreldlike objekte. Mens-wees is nie maar 'n toevallige "stuk" syn nie, maar 'n bepaalde manier van die teenwoordigheid van die syn in sy geheel. In mens-syn is syn "daar" as 
opgaaf: "Menschsein ist ... eine bestimmte Weise ... der Selbstgegebenheit des Seins im ganzen" (Metz 1962a:50-51). Dus: in die antroposentriese denkvorm "wird das Menschsein [Heidegger se Dasein] zur bevorzugten Erschließungsbasis für das Sein im ganzen" (Metz 1962a:51). In die subjektiwiteit word die syn in sy geheel ontsluit (Metz 1962a:52).

Subjektiwiteit is die beginsel waarvolgens beslis word tot watter mate 'n synde aan syn deelneem. Subjektiwiteit het 'n intellektuele en 'n wilsaspek: "Ein Seiendes steht in dem Maße im Sein inne, als es sich unaufhebbar zu sich selbst verhält ... und in diesem Selbstverhältnis 'bei sich' ist (intellectus) und sich selbst gehört (voluntas)" (Metz 1962a:52). 'n Verhouding tot die self is natuurlik slegs moontlik op grond van 'n afstand tot die self. Die self moet dus ingaan in die ander, maar sonder om dit daar te verloor. Dit moet by die ander en tegelyk by die self wees. Die self moet ook by die ander steeds aan die self behoort, die self bevestig, "affirmeer", "beja".

Hier volg Metz vir Karl Rahner (1957) wat in sy boek Geist in Welt: Zur Metaphysik der endlichen Erkenntnis bei Thomas von Aquin' 'n ontologiese verklaring van die menslike liggaamlikheid lewer. Dit vorm die basis van Rahner se begrip van concupiscentia. By Metz bied die herformulering van die verhouding tussen liggaam en siel binne 'n antroposentriese denkvorm die skakel na sy "teologie van die wêreld". Metz se tipering van die kosmosentriese denkvorm verdien nadere aandag, omdat dit kragtens die dialektiek van die Verligting weer relevant word vir die Politieke Teologie. Teenoor die antroposentrisme van Thomas en die Moderne is die Grieke se kosmosentriese denkvorm georiënteer aan die "welthafte Objektivität, die dinghaft-naturhafte, primär räumliche Vorhandenheit” (Metz 1962a:48). Die ontwerp van die syn wat in die kosmosentriese denke heers, is die orde van die dinge. Die mens word gesien as maar een van die dinge wat inpas in 'n model wat afgelees word van die orde van die materiële werklikheid. So gebeur dit dat "das menschliche Sein unter das Joch einer Vorstellung gerät, die es nicht in seiner Wahrheit, in seinem Ansich enthüllt, sondern verbirgt und verstellt" (Metz 1962a:48, voetnoot 11). Dit noem Metz die tragiek van die Grieke. Hy verwys na die denke van die Stoa as voorbeeld van hoe die waardigheid en integriteit van

3 Die eerste uitgawe van hierdie boek verskyn in 1939. Dit is oorspronklik as filosofiese doktorale dissertasie aangebied, maar afgekeur deur die promoter Martin Honecker, en Rahner moes Freiburg sonder sy doktorsgraad verlaat. Die tweede uitgawe, wat deur Metz "(i)m Auftrag des Verfassers überarbeitet und ergänzt" is, verskyn in 1957. 
die mens, alle pogings ten spyt, nie gedink kan word binne 'n kosmosentriese verstaanshorison nie:

Ihr geradezu leidenschaftlich betontes Bewußtsein von der Unversehrbarkeit und Unangreifbarkeit des menschlichen Ich bleibt im letzten tragisch verstrickt, denn es entfaltet sich in einem dafür heteronomen Seinsverständnis: das kosmozentrisch-objektivistische Seinsverständnis gibt den Blick auf die ursprüngliche Würde des menschlichen Individuums nicht frei. So erwächst der Dualismus und Tragizismus der griechischen Anthropologie schließlich aus diesem Seinsverständnis, in dem der Mensch, sosehr er inhaltlich als Maß aller Dinge gepriesen wird, in seiner Singularität verfehlt wird und als ein Teilstück unter die Herrschaft eines apersonalen Weltseins gerät.

(Metz 1962a:63-64)

'n Wisseling in verstaanshorison beloof dus bevryding van "die Herrschaft eines apersonalen Weltseins". So 'n wisseling oorwin die tragiek en die dualisme. Metz word hier so uitvoerig aangehaal omdat dit wat hy as die tragiek van die Grieke beskryf, kragtens die dialektiek van die Verligting, terugkeer as die vloek van die burgerlike maatskappy. Maar dit het Metz eers veel later ingesien, nadat hy aan Adorno blootgestel is. Sy eerste sekulariseringstese gee nog weinig blyke van hierdie bewussyn.

Die kontrastering van Griekse en Bybelse denke loop dwarsdeur Metz se teologiese ontwikkeling. In Christliche Anthropozentrik identifiseer hy Thomas met die deurbreek van Bybelse denke in die Griekse gees wat 'n verandering van denkvorm tot gevolg het. Sy eerste sekulariseringstese lui dat dit die Bybelse denkvorm is wat in die Moderne heers. Hierdie optimistiese bevestiging van die vryheidsgeskiedenis van die Moderne maak weldra plek vir profetiese kritiek op grond van die eskatologiese voorbehoud. Uiteindelik word dit vervang met 'n soort apokaliptiese kritiek. Die sekulariseringstese lui uiteindelik dat dit juis nie die denkvorm van die Bybel is wat in die Moderne tot heerskappy kom nie. Wel is die Bybelse denkvorm aanwesig in die strewe na vryheid, geregtigheid en solidariteit wat die Moderne kenmerk. Maar op die een of ander manier is dit die Griekse denkvorm wat geldig bly in die Moderne. Die "inhoude" wat gedink word - vryheid, geregtigheid, solidariteit (algemeenheid) - bly dus 
ondergeskik aan die vorm waarin dit gegiet word, die waarmee van die denke daaroor. En dit bly kosmosentries. Kosmos as "natuur" word tot "tweede natuur". Metz se beskrywing van die "tragiek van die Grieke" sou dus maklik verwar kon word met 'n paragraaf uit die maatskappykritiek van die kritiese teorie soos Metz dit weldra self leer beoefen. Die kritiek gaan uiteindelik sover dat Metz sy eie aanvanklike teologiese denke, en dus die teologie van sy leermeester, tipeer as steeds gevange in die Griekse denkvorm. 'n Werklike ommekeer, bekering, tot die Bybelse denkvorm wat tegelyk 'n antropologiese rewolusie behels, word die eis van die Politieke Teologie. Om uiteindelik te verstaan wat hy daarmee bedoel, is dit eers nodig om Metz se aanvanklike sekulariseringstese kortliks te beskryf.

\subsubsection{Die sekulariseringstese}

In Christliche Anthropozentrik word die oorgang na 'n teologie van die wêreld reeds voorberei. Die sekulariseringstese is die basis van hierdie oorgang. "Die Welt ist heute weltlich geworden," stel Metz (1968:11) in 'n sleutelteks vas. Dit is die taak van die teologie om "die jeweiligen Weltzeit zu verstehen und zu verantworten." Teen die negering van die wêreldlikheid van die wêreld, op daardie stadium in Rooms-Katolieke kringe nog eerder die reël, stel Metz (1968:16-17) sy sekulariseringstese:

Die Weltlichkeit der Welt, wie sie im neuzeitlichen Verweltlichungsprozeß entstand und in global verschärfter Form uns heute anblickt, ist in ihrem Grunde, freilich nicht in ihren einzelnen geschichtlichen Ausprägungen, nicht gegen, sondern durch das Christentum entstanden; sie ist ursprünglich ein christliches Ereignis und bezeugt damit die innergeschichtlich waltende Macht der "Stunde Christi" in unserer Weltsituation.

Die teologiese grond vir hierdie stelling werk Metz (1968:17) uit in aansluiting by die vraag na wat in Jesus Christus vir ons wêreldverstaan gebeur het. Die antwoord: "Gott hat die Welt in endzeitlicher Definität angenommen in seinem Sohn Jesus Christus" (Metz 1968:18; vgl 2 Kor 1:19-20). Die kerk is die histories sigbare en werksame teken, die sakrament van die eskatologies finale aangenomenheid van die wêreld deur God 
(Metz 1968:18). Hierdie stelling sal deeglik onder loep geneem word in deel 2 van hierdie artikel.

\subsubsection{Die kategorie "wêreld"}

Die antroposentriese denkvorm behels dat ontologie as antropologie bedryf word. 'n Kenmerk van 'n antroposentriese antropologie is dat dit die mens beskryf as eenheidswese, as eenheid van liggaam en siel. Metz se verstaan van die kategorie "wêreld" berus op 'n ontologiese verklaring van menslike liggaamlikheid of sinlikheid wat deur Rahner (1957) uitgewerk is.

Metz (1962a:28, voetnoot 5) kondig in Christliche Anthropozentrik 'n boek aan met die tema "Die Leibhaftigkeit des Heils". Die woord "Leibhaftigkeit" is ongelukkig onvertaalbaar in Afrikaans. Daar moet volstaan word met "liggaamlikheid" as liggaam die geleefde en beleefde liggaam is. Dat heil "leibhaftig" (liggaamlik) is, volg uit 'n antropologie wat ' $n$ mens sien as eenheid van liggaam en siel, 'n siening wat slegs op grond van die antroposentriese denkvorm moontlik is (Metz 1962a:70-73).

Die boek, wat uitvoerig oor concupiscentia sou handel, het toe nooit verskyn nie. Daar is wel 'n aantal sleuteltekste beskikbaar wat 'n aanduiding gee van die gang van Metz (1961a, 1962b, 1963; Metz \& Fiorenza 1967) se denke oor liggaaam en siel, geestelik en wêreldlik, en oor sy hantering van die begrip concupiscentia binne hierdie verbande. Volgens Metz is liggaam en siel nie twee afsonderlike dele van die een mens nie, maar die een mens is geheel en al liggaam en geheel en al siel. Die een is werklik as die werklikheid van die ander. Die siel is slegs werklik as dit uitdrukking vind in ruimte en tyd, in die liggaam. Die liggaam is die siel soos dit daar is in die wêreld (Metz 1962b:103). Subjektiwiteit, "Beisichsein", kan dus slegs bestaan as beliggaamde siel en besielde liggaam. Die een en hele mens is in totaliteit besield en in totaliteit liggaamlik, "als ganzer 'Subjektivität' und als ganzer welthafte Zuständigkeit, als ganzer 'Existenz' und als ganzer 'Situation'; ... das eine wirklich als die Wirklichkeit des anderen" (Metz 1962a:72). Liggaamlikheid beteken dus dat 'n mens altyd alreeds stelling ingeneem het:

Leib is eine ursprüngliche "Befindlichkeit" des Menschen, von der er sich durch keine Reflexion distanzieren kann, in die er immer schon eingelassen ist und die er immer schon bejaht und vollzieht, wenn er in seinen Akten sich 
selbst bestimmt, auf sich selbst zugeht und wachsend sich selbst in Freiheit verwirklicht. In all seinen Selbstvollzügen ist der Mensch je schon eingetreten in das Leiblich-Welthafte... .

(Metz 1962b:104)

"Wêreld" is die "situasie" waarin 'n mens as besielde liggaam en beliggaamde siel jou bevind op grond van jou liggaamlikheid. Wêreld is die situasie waarbinne 'n mens mens word. Die wêreld is dus nie (kosmosentries) 'n voorgegewe "objek" nie, 'n vreemde "ander" ten opsigte van die subjek nie, nie die absoluut wederstrewige met betrekking tot die vryheid van die subjek nie. Wêreld is (antroposentries) die "waarin" van die menswording van die mens (Metz 1962a:68). En om mens te word moet perspektief verkry word deur afstand te neem (vgl Degenaar 1963). 'n Mens is altyd reeds in die wêreld: "Dieses welthafte Außersichsein ist ... keine (nachträgliche) Bestimmung des konstituierten Menschen, sonder Grundzug seiner ontologischen Konstitution" (Metz 1962a:69). Belangrik is dat Metz (1962a:70) die historiese aard van "wêreld" beklemtoon, al domineer hier nog Heidegger se "Geschichtlichkeit". Die wêreld word tot wêreld deur menslike selfverwerkliking.

Hiermee word reeds 'n grondslag gelê vir die formulering van 'n politieke teologie. In die opstelle gebundel in Zur Theologie der Welt bou Metz (1968) voort op hierdie grondslag. Hierdie ontwikkelinge in Metz se denke word in die volgende afdeling nagegaan, waarna die volgende belangrike wending aandag sal kry, te wete dié van 'n kategorisering van "wêreld" as primêr geskiedenis tot die kategorisering van wêreld as geskiedenis en maatskappy.

Eers moet nog 'n oomblik verwyl word by Metz se beskrywing van concupiscentia binne die verbande wat hierbo daargestel is. Metz (1977:31-33) se privatiseringstese wat so 'n sentrale plek inneem in sy Politieke Teologie kan met concupiscentia in verband gebring word op grond van die volgende uitspraak:

Wenn sich ... in unserer nachadamitischen Heilssituation die Gnade nicht total durchsetzt und ausprägt in der aktuellen Präsenz des leiblichen Seins, sondern mehr oder weniger isoliert bleibt auf das "rein Seelische", "rein Innerliche", 
so drückt sich darin material immer auch etwas Nichtsein-Sollendes und in diesem Sinne stets neu und immer mehr zu Überwindendes aus...

(Metz 1963:31)

Die feit dat die genade onvoldoende uitdrukking vind in die liggaam, in die wêreld, hang met concupiscentia saam: "Leib ist nicht nur Öffnung und Aufbruch, sondern auch 'Einbruch' von außen, Ausgesetztheit, Bedrohung' (Metz 1962b:105). Die openheid vir die ander is tegelyk 'n openheid vir die vreemde. En as gevolg van die wesenlikheid van liggaamlike bestaan, is enige vlug voor die vreemde in 'n gewaande veilige en onbereikbare innerlikheid tevergeefs. Menslike vryheid is kragtens liggaamlikheid altyd uitgelewerde vryheid. Menslike vryheid word nie bewys in protes teen die bedreiging wat met liggaamlikheid gepaard gaan nie, maar in gehoorsaamheid:

Nicht Entwurf, sondern Übernahme, nicht schweifende Willkür, sondern gehorsame Annahme ist das Stigma der Freiheit unseres leibhaftigen Seins: ihre Kunst ist es, sich mit dem unvermeidlich Auferlegten innerlich zu verständigen; ihre Kunst, schließlich liebend zu können, was man muß, in der Ohnmacht der Not die Macht der Hingabe zu bewähren. Leibliche Freiheit kann konkret nie als selbstherrliche, sondern immer nur als sich hingebende Freihet - als Passion bestanden werden.

(Metz 1962b:106)

Wat Metz hier beskryf, is die "integriteit" van Jesus van Nasaret wat van hom die Christus maak: "Einer ... ist den Weg der Erde, den Weg der Menschen zu Ende gegangen; einer hat sich der konstitutionellen Bedrohtheit und Versuchtheit unseres leiblichen Daseins nicht im letzten noch einmal verweigert wie wir..." Die teologie van die wêreld, en uiteindelik die Politieke Teologie, is die konsekwensie van die teologie van die inkarnasie, van die integriteit van Jesus wat bestaan in sy aanname van die wêreld. Terwyl concupiscentia in die eng, teologiese sin van die woord verwys na die protes teen die menslike situasie van radikale blootstelling aan die ambivalensie wat met 
liggaamlikheid gegee is, beteken die navolging van Christus daarteenoor juis die uithou van die teenstrydighede.

\section{Literatuurverwysings}

Adorno, Th W 1951. Minima Moralia: Reflexionen aus dem beschädigten Leben. Frankfurt/aM: Suhrkamp.

Caputo, J D 1987. Radical hermeneutics: Repitition, deconstruction and the hermeneutic project. Bloomington: Indiana University Press. (Studies in Phenomenology and Existential Philosophy.)

Degenaar, J J 1963. Die sterflikheid van die siel. Johannesburg: Simondium.

Deleuze, G 1985. Nietzsche und die Philosophie: Aus dem Französischen von Bernd Schwibs. Frankfurt/aM: Syndikat. (Taschenbücher Syndikat, EVA 70.)

Gadamer, H-G 1986. Hermeneutik, I: Wahrheit und Methode. Grundzüge einer philosophischen Hermeneutik. Tübingen: Mohr. (Gesammelte Werke, Bd 1.)

Heidegger, M 1961. Nietzsche, Zweiter Band. Pfullingen: Neske.

Heidegger, M 1971. Schellings Abhandlung über das Wesen der menschlichen Freiheit (1809). Herausgegeben von Hildegard Feick. Tübingen: Niemeyer.

Heidegger, M 1976. Wegmarken. Gesamtausgabe, Bd 9. Frankfurt/aM: Klostermann. Heidegger, M 1977. Sein und Zeit. Gesamtausgabe, Bd 9. Frankfurt/aM: Klostermann. Heidegger, M 1991. Kant und das Problem der Metaphysik. (Gesamtausgabe, 1. Abteilung, Bd. 3). Frankfurt/aM: Klostermann.

Hofmeyr, H M 1997. 'n Teologie van die verlange: Concupiscentia in die Politieke Teologie van Johann Baptist Metz. DD-proefskrif, Universiteit van Pretoria.

Jäger, A 1978. Gott: Nochmals Martin Heidegger. Tübingen: JCB Mohr (Paul Siebeck).

Kant, I 1976. Kritik der reinen Vernunft. Nach der ersten und zweiten Original-Ausgabe neu herausgegeben von Raymund Schmidt. Hamburg: Felix Meiner. (Philosophische Bibliothek, 37a.)

Metz, J B 1953. Heidegger und das Problem der Metaphysik. Scholastik 28, 1-22.

Metz, J B 1956. Herr, wir danken Dir für diese Kirche. Geist und Leben 29, 321-322.

Metz, J B 1961a. Leib. Lexikon für Theologie und Kirche 4, 902-905. 
Metz, J B 1961b. Armut im Geiste: Vom Geist der Menschwerdung Gottes und der Mensch-Werdung des Menschen. Geist und Leben 34, 419-435.

Metz, J B 1962a. Christliche Anthropozentrik: Über die Denkform des Thomas von Aquin. Mit einführendem Essay von Karl Rahner. München: Kösel.

Metz, J B 1962b. Caro Cardo salutis: Zum christlichen Verständnis des Leibes. Hochland 55, 97-107.

Metz, J B 1963. Leiblichkeit. Handbuch theologischer Grundbegriffe 2, 30-37.

Metz, J B 1968. Zur Theologie der Welt. Mainz: Grünewald.

Metz, J B 1977. Glaube in Geschichte und Gesellschaft: Studien zu einer praktischen Fundamentaltheologie. Mainz: Grünewald.

Metz, J B 1980. Faith in history and society: Toward a practical fundamental theology. New York: Seabury.

Metz, J B 1984. Im Angesichte der Juden: Christliche Theologie nach Auschwitz. Concilium 20, 382-389.

Metz, J B 1994. Lob der Negativen Theologie: Aus einem Interview zur Gottesfrage, in Lutz Bachman, M (Hrsg), Und dennoch ist von Gott zu reden: Festschrift für Herbert Vorgrimler, 304-310. Freiburg: Herder.

Metz, J B \& Fiorenza, FP 1967. Der Mensch als Einheit von Leib und Seele, Mysterium Salutis, Bd. 2, 584-636. Einsiedeln: Benzinger.

Nietzsche, F 1964a. Zur Genealogie der Moral: Eine Streitschrift, 237-412. Stuttgart: Kröner. (Sämtliche Werke in zwölf Bänden 7.)

Nietzsche, F 1964b. Der Antichrist, 189-283. Stuttgart: Kröner. (Sämtliche Werke in zwölf Bänden, Bd 8.)

Pöggeler, 1975. Being as appropriation. Philosophy Today 19, 152ff.

Rahner, K 1954. Zum theologischen Begriff der Konkupiszenz, in Schriften zur Theologie, Bd. 1, 344-414. Einsiedeln: Benzinger.

Rahner, K 1957. Geist in Welt: Zur Metaphysik der endlichen Erkenntnis bei Thomas von Aquin. Im Auftrag des Verfassers überarbeitet und ergänzt von J.B. Metz. München: Kösel.

Rahner, K 1963. Hörer des Wortes: Zur Grundlegung einer Religionsphilosophie. Neu bearbeitet von J.B. Metz. München: Kösel. 
Schoeman M J 1978. Heidegger: Denker in die skaduwee van die Nihilisme. HTS 34(3), 120-130.

Shapiro, M J 1984. Literary production as a politicizing practice, in Shapiro M J (ed), Language and politics: Readings in social and political theory, 213-253. Oxford: Basil Blackwell.

Sheehan, T 1987. Karl Rahner: The philosophical foundations. Athens, Ohio: Ohio University Press.

Sonnemann, U 1969. Negative Anthropologie: Vorstudien zur Sabotage des Schicksals. Hamburg: Rowolt.

Vattimo, G 1993. The adventure of difference: Philosophy after Nietzsche and Heidegger, tr by C Blamires with the assistance of T Harrison. Cambridge: Polity Press.

Young, D 1992. Origins of the sacred: The ecstasies of love and war. London: Little, Brown and Company. 